\title{
The circadian clock regulates cisplatin-induced toxicity and tumor regression in melanoma mouse and human models
}

\author{
Panshak P. Dakup ${ }^{1}$, Kenneth I. Porter $^{1}$, Alexander A. Little ${ }^{1}$, Rajendra P. Gajula ${ }^{1}$, \\ Hui Zhang ${ }^{1}$, Elena Skornyakov ${ }^{2,3}$, Michael G. Kemp ${ }^{4}$, Hans P.A. Van Dongen ${ }^{2,5}$ and \\ Shobhan Gaddameedhi, ${ }^{1,2}$ \\ ${ }^{1}$ Department of Pharmaceutical Sciences, College of Pharmacy, Washington State University, Spokane, WA, USA \\ ${ }^{2}$ Sleep and Performance Research Center, Washington State University, Spokane, WA, USA \\ ${ }^{3}$ Department of Physical Therapy, Eastern Washington University, Spokane, WA, USA \\ ${ }^{4}$ Department of Pharmacology and Toxicology, Wright State University Boonshoft School of Medicine, Dayton, OH, USA \\ ${ }^{5}$ Elson S. Floyd College of Medicine, Washington State University, Spokane, WA, USA \\ Correspondence to: Shobhan Gaddameedhi, email: shobhan.gaddameedhi@wsu.edu \\ Keywords: circadian rhythm; DNA repair; cisplatin; toxicity; melanoma \\ Received: December 19,2017 Accepted: February 10, 2018 Epub: February 20, 2018 Published: March 06, 2018 \\ Copyright: Dakup et al. This is an open-access article distributed under the terms of the Creative Commons Attribution License \\ 3.0 (CC BY 3.0), which permits unrestricted use, distribution, and reproduction in any medium, provided the original author and \\ source are credited.
}

\section{ABSTRACT}

Cisplatin is one of the most commonly used chemotherapeutic drugs; however, toxicity and tumor resistance limit its use. Studies using murine models and human subjects have shown that the time of day of cisplatin treatment influences renal and blood toxicities. We hypothesized that the mechanisms responsible for these outcomes are driven by the circadian clock. We conducted experiments using wild-type and circadian disrupted Per $1 / 2^{-/-}$mice treated with cisplatin at selected morning (AM) and evening (PM) times. Wild-type mice treated in the evening showed an enhanced rate of removal of cisplatin-DNA adducts and less toxicity than the morning-treated mice. This temporal variation in toxicity was lost in the Per $1 / 2^{-/-}$ clock-disrupted mice, suggesting that the time-of-day effect is linked to the circadian clock. Observations in blood cells from humans subjected to simulated day and night shift schedules corroborated this view. Per $1 / 2^{-/-}$mice also exhibited a more robust immune response and slower tumor growth rate, indicating that the circadian clock also influences the immune response to melanoma tumors. Our findings indicate that cisplatin chronopharmacology involves the circadian clock control of DNA repair as well as immune responses, and thus affects both cisplatin toxicity and tumor growth. This has important implications for chronochemotherapy in cancer patients, and also suggests that influencing the circadian clock (e.g., through bright light treatment) may be explored as a tool to improve patient outcomes.

\section{INTRODUCTION}

Cisplatin (cis-Diamminedichloridoplatinum) is one of the most commonly used chemotherapeutic agents for the treatment of a variety of cancers, including testicular, lung, bladder, cervical, and ovarian [1]. Cisplatin is regarded as the "penicillin of cancer drugs" due to its universal and dynamic application at different stages of cancer therapy, for neoadjuvant or adjuvant purposes, as either a mono or combination therapy $[2,3]$. According to ClinicalTrials.gov, there are over 1,000 active clinical trials involving cisplatin for the treatment of various cancer types, including melanoma [4]. The general cisplatin treatment regimen involves intravenous injection of $50-120 \mathrm{mg} / \mathrm{m}^{2}$ of body surface area every 3-4 weeks [5]. The mode of action of cisplatin is in its ability to 
crosslink with purine bases on the DNA to form bulky adducts, which interfere with DNA replication and gene transcription [5]. While experimental and clinical efforts have been made to optimize this mechanism to specifically fight tumors, there are two major limitations to the use of cisplatin: tumor resistance and toxicity, including nephrotoxicity, ototoxicity, and leucopenia [3].

Melanoma is mainly associated with chemotherapy resistance, especially with cisplatin [6]. Melanoma, also known as malignant or cutaneous melanoma, is the most aggressive form of skin cancer in humans and originates in specific cell types called melanocytes located in the epidermis of the skin [7]. Though melanoma represents $1-2 \%$ of all skin cancer types, it contributes to $71-80 \%$ of skin cancer-related deaths due to its high metastatic potential and resistance to therapy [8]. Genetic alterations within melanocytes create antigenic epitopes which are recognized by the host immune system [9]. Most of the antigens expressed in melanoma tumors are recognized by $\mathrm{CD}^{+}$and $\mathrm{CD}^{+} \mathrm{T}$ cells, which have cytotoxic functions and are capable of infiltrating tumor sites $[9,10]$. While other forms of therapy such as immunotherapy are investigated for melanoma, cisplatin is still being used mostly as an adjuvant therapy, with 30 clinical trials active or recently completed $[1,4]$.

One promising approach for improving patient outcomes with cisplatin treatment may be chronochemotherapy, which is the administration of cancer treatment(s) at specific times of the day to maximize efficacy and/or minimize toxicity [11]. The concept of chronotherapy is embedded in the biology of circadian rhythms [12], which regulates numerous physiological processes with a periodicity of $\sim 24$ hours, including cell proliferation, DNA repair via nucleotide excision repair (NER), immune function, the sleep-wake cycle, and responses to therapeutic treatment [13-17]. Circadian rhythms are generated by an endogenous biochemical/molecular time-keeping mechanism known as the circadian clock, which comprises a master clock located in the suprachiasmatic nucleus (SCN) of the brain and peripheral clocks located in almost every cell throughout the body [13].

The circadian system is a genetically encoded, anticipatory mechanism that underlies both geneenvironment and brain-behavioral interactions and synchronizes most of the body's biological processes with the time of day [18]. At the molecular level, the primary process driving this mechanism is a cell-autonomous and self-sustained transcriptional-translational feedback loop (TTFL) [16]. The core clock proteins CLOCK and BMAL1 activate the transcription of many clockcontrolled genes, including period (PER1/2/3) and cryptochrome $(C R Y 1 / 2)$, by binding to E-box elements in their promoters. The $P E R$ and $C R Y$ transcripts are exported from the nucleus to the cytoplasm where their protein products form a CRY/PER protein complex. After a time delay, the negative (primary) arm of the feedback loop translocates the CRY/PER dimeric protein complex back into the nucleus to translationally inhibit CLOCK/ BMAL1-mediated transactivation, and thereby inhibit their own transcription [13, 19-21]. The positive (secondary) arm elements of the feedback loop, RORs and REV-ERBs, regulate the clock by activating and repressing BMAL1, respectively [22]. The effects of this molecular clock are wide-spread. As many as $43 \%$ of protein-coding genes in mouse show circadian rhythmicity, often in a tissuespecific manner [23]. More than 170 drug targets are clock controlled genes, including targets of 56 of the top 100 best-selling drugs in United States [23].

Although the circadian-mediated tolerability and efficacy of anti-cancer drug exposure and disposition following drug administration at different times of day was documented over 30 years ago [24, 25], its impact on clinical practice is limited due to insufficient understanding of the molecular mechanisms behind the experimental observations [26]. Studies in murine models and human subjects have shown better outcomes with decreased renal toxicity and body weight (rodents), and 2-4 times reduced treatment-related complications such as bleeding, infection, and transfusions (humans) with genotoxic stress inducing anti-cancer agents, including cisplatin, when administered in the evening as compared to the morning [11, 24, 25, 27-32]. Thus, by harnessing the clock-regulated DNA repair capabilities of normal cells relative to tumor cells, treatment efficacy may be maximized and/or toxicity may be reduced.

The focus of this study was to understand the chronopharmacological effects and associated mechanisms of cisplatin therapy. We provide a mechanistic, circadian clock-based account of the DNA damage response to cisplatin-induced DNA lesions via the NER system and the immune response against melanoma tumors.

\section{RESULTS}

\section{The circadian clock regulates the repair of cisplatin-DNA adducts in mouse kidney and spleen}

Given that nephrotoxicity is the major side effect associated with cisplatin treatment, we measured the accumulation of cisplatin-DNA adducts $(\mathrm{Pt}-(\mathrm{GpG}))$ in vivo in kidney, liver, testis, and brain tissues of mice treated with cisplatin for 2 hours (Supplementary Figure 1A). Our results with various doses of cisplatin clearly show that the kidney is the major site of cisplatin-DNA adduct formation, similar to what was shown in a kinetic analysis of cisplatin-DNA adduct formation [33]. We assessed the repair of these adducts in kidney tissues to determine if it was affected by the time of day of treatment. We treated two groups of mice with a single $2.5 \mathrm{mg} / \mathrm{kg}$ dose of cisplatin at Zeitgeber Time (ZT) 0 (ZT0 is the time 
of lights on), which corresponds to an early morning hour (7 AM), or ZT12, which corresponds to an early evening hour (7 PM). This dose was sufficient to induce DNA damage in kidneys [34] (for dose comparison, see Table 1). Alongside the cisplatin treatment group, there was a negative control group treated with saline. Kidney tissues were harvested from 2 to 98 hours post-treatment. Figure 1A shows that with evening treatment of cisplatin, there were fewer cisplatin-DNA adducts remaining in wild-type kidney tissues between 50 and 98 hours after treatment compared to the morning treatment with cisplatin. This result is consistent with recent findings in mouse liver tissues [34]. Furthermore, XPA, a clockcontrolled gene that is the rate-limiting factor for cisplatinDNA adduct removal by NER, was expressed at a higher level in the evening compared to the morning in mouse kidneys (Figure 2C) [35]. Collectively, these results suggest enhanced repair of cisplatin-DNA adducts in the evening compared to the morning, as confirmed by the repair kinetics in Figure 1B extrapolated from the immuno-slot blot data in Figure 1A.

We compared our findings in the wild-type mice to genetically circadian-disrupted Per $1 / 2$ mutated mice $\left(\operatorname{Per} 1 / 2^{--/}\right)$that lack endogenous circadian rhythmicity [36]. We treated both groups of mice at ZT0 (morning) or ZT12 (evening) with a single $7 \mathrm{mg} / \mathrm{kg}$ dose of cisplatin, a dose physiologically comparable to current clinical applications $[27,37]$. We obtained similar results in the kidney and spleen, such that better repair of cisplatin adducts was observed in the evening treated group of wild-type mice (Figures 1C, 1D). However, we observed no time-of-day difference of cisplatin repair in kidney and spleen from the Per $1 / 2^{-/}$mice. In addition, there was no difference in XPA protein levels in the morning and evening groups of Per $1 / 2^{--}$mice (Figure $2 \mathrm{C}$ ). Hence, the circadian clock appears to play an important regulatory role in the repair of cisplatin-DNA adducts in kidney and spleen tissues, as correlated with expression of the core NER factor XPA.

\section{The circadian clock attenuates cisplatin- associated toxicity in melanoma mouse model}

Next, we investigated how the temporal modulation of cisplatin therapy affects its toxicity in a B16F10 melanoma mouse model. Our model in Figure 2A shows the timeline for this experiment. We injected B16F10 melanoma tumor cells $\left(2 \times 10^{5}\right.$ cells/mouse $)$ subcutaneously into the lower right flank region of wildtype and Per $1 / 2^{-/}$mice. These cells began to form visible tumors 1 week after injection. On day 0 , when tumor sizes were an average of $200 \mathrm{~mm}^{3}$ ( $\sim 10$ days post-injection), both wild-type and Per $1 / 2^{-/}$mice were subdivided randomly into three treatment groups: saline, cisplatin treatment at ZT0 (morning), or cisplatin treatment at ZT12 (evening). A $5 \mathrm{mg} / \mathrm{kg}$ dose of cisplatin was administered on days 1 and 3 , and whole-body weight, used as a measure of toxicity, was recorded before each treatment and then on days $6,8,10,12$ and 14 after the first dose. Figure 2B shows that in wild-type mice, relative to the saline-treated group, there was a greater decrease $(\mathrm{p}<0.05)$ in body weight in the morning-treated group compared to the evening-treated group on days 6 and 8 . Further, through the 14 days, body weights showed better recovery in the evening-treated group compared to the morning-treated group. Even with a higher dose treatment of $21 \mathrm{mg} / \mathrm{kg}$ of total cisplatin $(7 \mathrm{mg} / \mathrm{kg}$ three times), the evening-treated wild-type mice exhibited overall better body weight recovery (Supplementary Figure 2A). These data are consistent with better repair of DNA damage and less toxicity in mice that received evening treatment of cisplatin (Figure 1).

Surprisingly, the body weights of $10 \mathrm{mg} / \mathrm{kg}$ cisplatintreated Per $1 / 2^{-/}$mice showed the same trend as the wildtype mice, with the morning-treated group of the Per $1 / 2^{-1-}$ mice experiencing greater weight loss $(\mathrm{p}<0.05)$ compared to the evening-treated group (Figure 2B). Additionally, the trend of body weight recovery was similar in both the wildtype and Per $1 / 2^{-/-}$mice, except for a sudden decrease in the evening-treated Per $1 / 2^{-/}$group by day 14 . This similar trend might be due to light entrainment effect in Per $1 / 2^{-/-}$mice. With the higher dose of $21 \mathrm{mg} / \mathrm{kg}$, the difference between morning- and evening-treated groups appeared to be lost (Supplementary Figure 2B), which may be due to severe toxicity of the high dose of cisplatin.

To further understand the molecular pathways and factors responsible for the time-of-day modulated toxicities, we probed selected proteins involved in DNA repair and proliferation and the core circadian clock in kidney. First, we probed proteins in kidney tissues collected up to 4 days post-cisplatin treatment in non-tumor bearing mice (Figure 2C). In saline-treated wild-type mice, the repair, clock, and replication proteins (Xpa, Bmall, and Pcna, respectively) are expressed in a circadian manner, with increased levels in the evening compared to the morning [38]. These timeof-day differences are not present in the Per $1 / 2^{-/-}$mice [35]. In both morning- and evening-treated wild-type and Per $1 / 2^{-/}$mice, the downstream effects of cisplatin treatment showed an increase in induced DNA damage through $\gamma \mathrm{H} 2 \mathrm{a}$.x phosphorylation levels representing the activation of DNA damage response kinases ATR and ATM (Figure 2C). Interestingly, the endogenous level of $\gamma \mathrm{H} 2 \mathrm{a} . \mathrm{x}$ phosphorylation was elevated in the control groups of the $\operatorname{Per} 1 / 2^{-/-}$mice compared to the wild-type mice, which is consistent with a molecular clock disrupted Bmal1 ${ }^{-/}$mouse model [39].

The damage signal was increased at 2 hours and reduced at 96 hours in the evening-treated wild-type mice but not in the morning-treated wild-type and morning- or evening-treated Per $1 / 2^{-/}$mice, because the cisplatin adducts were removed, consistent with the cisplatin-caused DNA adduct repair shown in Figure 1C. Replication, DNA repair, and clock proteins were all drastically reduced 2 hours after 
Table 1: Cisplatin dose comparison table

\begin{tabular}{lc}
\hline \multicolumn{2}{c}{ In vivo $[37,68,69]$} \\
\hline Mouse (mg/kg) & Human $\left(\mathbf{m g} / \mathbf{m}^{2}\right)$ \\
\hline 2.5 & 7.5 \\
5 & 15 \\
7 & 21 \\
10 & 30 \\
$15.5\left(\mathrm{LD}_{10}\right)$ & 45 \\
\hline \multicolumn{2}{c}{ Ex vivo $[\mathbf{7 0 , 7 1 ]}$} \\
\hline Cell line dose $(\boldsymbol{\mu M})$ & Cell line dose $(\boldsymbol{\mu g} / \mathrm{ml})$ \\
\hline 10 & 3 \\
\hline
\end{tabular}

cisplatin treatment and slowly recovered by 96 hours in all groups, as seen in the levels of Pcna, Xpa, and Bmall, respectively. This might be due to an enrichment of repair proteins on chromatin, which we were unable to extract using whole tissue lysate, or it might suggest that cisplatin affects the circadian clock and its regulated processes.
Underlying the dosing time-dependent toxicity of cisplatin treatment (Figure 2B) are the circadian expressions of repair and clock proteins (Xpa and Bmal1 respectively), which are elevated in the evening in the wild-type groups (Figure 2C). We probed protein levels in kidney tissues collected at ZT12 on day 16 post-cisplatin treatment in tumor bearing mice (Figure 2D). In wildtype and Per $1 / 2^{-/}$mice, we found that p53 levels were higher in the morning-treated kidney tissues compared to the evening-treated group, consistent with the weight loss phenotype. Surprisingly, the levels of DNA damage response in the evening-treated groups were increased compared to the morning-treated groups. This might be due to increased single-strand DNA levels, as seen with increased levels of Rpa32/rpa2.

\section{Circadian clock disruption by Per1/2 loss enhances immune response to melanoma tumors}

We measured tumor volumes to determine whether the clock influences melanoma tumor growth/shrinkage following cisplatin treatment. Figures 3A-3B show tumor
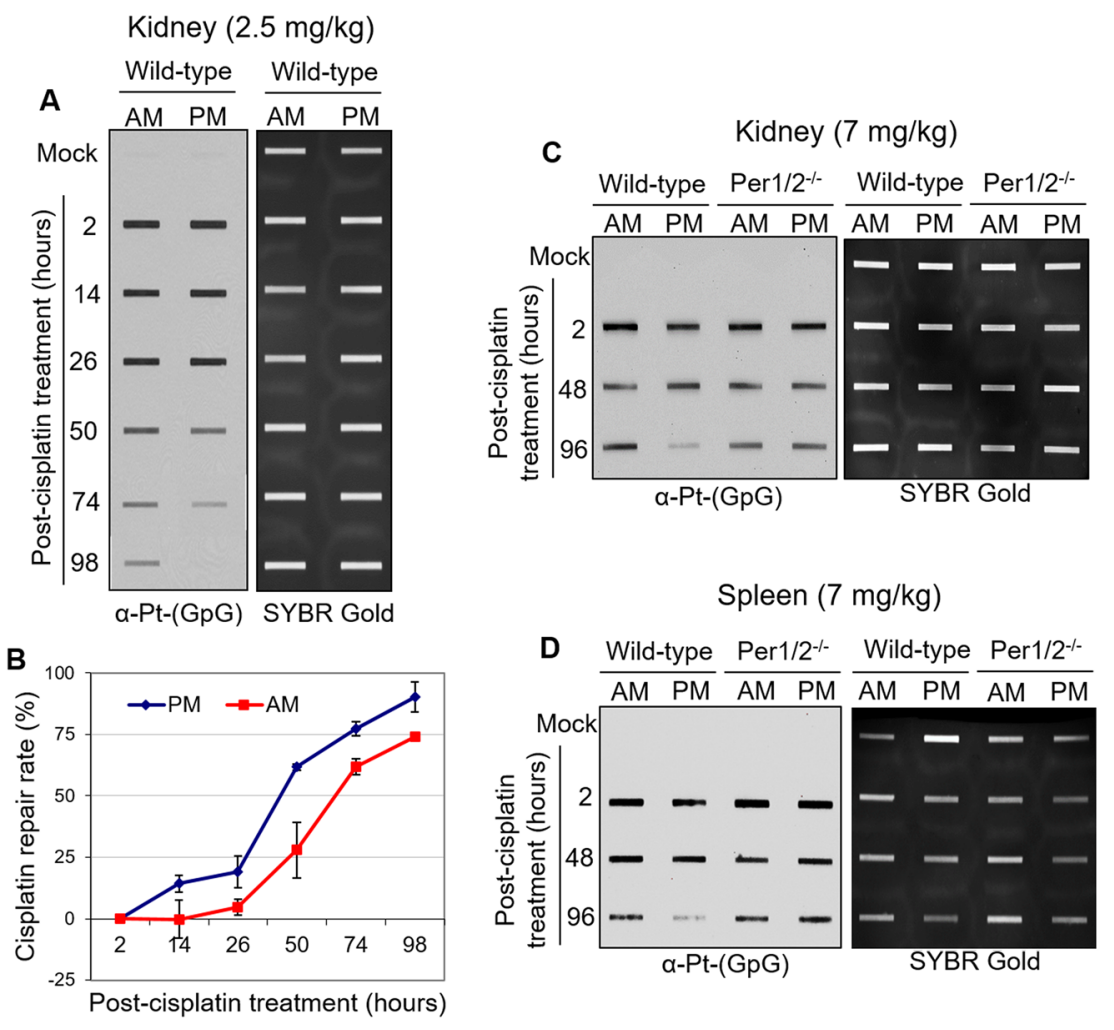

Figure 1: Immuno-slot blot analysis of cisplatin repair by time of day in C57BL/6 mouse tissues. (A) C57BL/6 wild-type mice kept under LD12:12 cycle were injected with $2.5 \mathrm{mg} / \mathrm{kg}$ of cisplatin (i.p.) either in the morning (7 AM, ZT0) or evening (7 PM, ZT12). Mice were sacrificed and kidney and spleen tissues were collected at different times between 2 and 98 hours after treatment, and snap frozen for storage and further processing. Genomic DNA was isolated and probed for levels of cisplatin-DNA adducts with an $\alpha$-Pt$(\mathrm{GpG})$ antibody in a slot-blot experiment. SYBR Gold was used as an internal control. (B) Cisplatin-DNA adduct repair was quantified from experiments performed as in (A). Error bars represent means $\pm \mathrm{SD}$ ( $\mathrm{n}=2$ mice at each time point with a total of $24 \mathrm{mice})$. C57BL/6 wild-type mice were compared to genetically circadian-disrupted Per $1 / 2^{-/-}$mice in the levels of cisplatin-DNA adducts in the kidney (C) and spleen (D) after $7 \mathrm{mg} / \mathrm{kg}$ cisplatin treatment in the morning (7 AM, ZT0) or evening (7 PM, ZT12). 
volume represented as a fold change relative to the volume at the start of treatment, in both wild-type and Per $1 / 2^{-/-}$ mice. Linear regression analysis confirmed that cisplatin treatment slowed tumor growth, such that it took 2-4 days longer for tumors to increase 4- to 5-fold in volume in the cisplatin-treated animals than in the saline-treated animals. In Per $1 / 2^{-/}$mice treated with cisplatin in the morning, tumors grew at a significantly slower rate $(\mathrm{p}<0.05)$ relative to saline-treated tumors (Supplementary Figure $3 \mathrm{~B})$. As such, there appears to be some potential for the loss of per $1 / 2$ genes in the host to enhance the treatment of tumors.

To find out whether the effectiveness of the treatment on wild-type mice was dose-dependent, we conducted a second, similar experiment, keeping all experimental variables constant but increasing the dose to three treatments of $7 \mathrm{mg} / \mathrm{kg}$ each. Our results showed a significant decrease in the tumor growth rate of wild-type mice by day 12 , irrespective of time of day of treatment, compared to the saline-treated tumors (Supplementary Figure 2C). Again, the Per $1 / 2^{-/-}$mice displayed significantly less tumor growth relative to saline treatment, especially with morning cisplatin treatment, crossing the 5-fold increase mark by day 14, 2 days later than the wild- types (Supplementary Figure 2D). Our observations in both the low and high dose groups may be due to clock dysfunction within the tumor cells [40]. Nevertheless, these results indicate that cisplatin was more effective at reducing tumor growth rate in the Per $1 / 2^{-/-}$mice in a dosedependent manner.

After observing that the Per $1 / 2^{-/-}$mice had better cisplatin treatment efficacy against melanoma tumors with both low and high doses, we sought to identify underlying contributing factors. Melanoma tumor cells express antigens that are recognizable by the host $\mathrm{CD}^{+}$ $\mathrm{T}$ cells, which kill tumor cells, and whose induction and recruitment are mediated by $\mathrm{CD}^{+}$helper T cells $[10,41$, 42]. We performed a separate experiment aimed to identify immune response to melanoma tumors in the wild-type and Per $1 / 2^{---}$mice. We had a non-tumor (control) group and a melanoma tumor (experimental) group without cisplatin treatment. The animals were sacrificed 15 days after injection of B16F10 melanoma tumor cells, and tumor volumes showed no significant difference between the wild-type and Per1/2-/ groups (data not shown). In the non-tumor mice, cell phenotyping by flow cytometry revealed that the gated $\mathrm{CD}^{+} \mathrm{T}$ cell population was significantly higher in circulating blood and spleen tissues

\section{Study design}
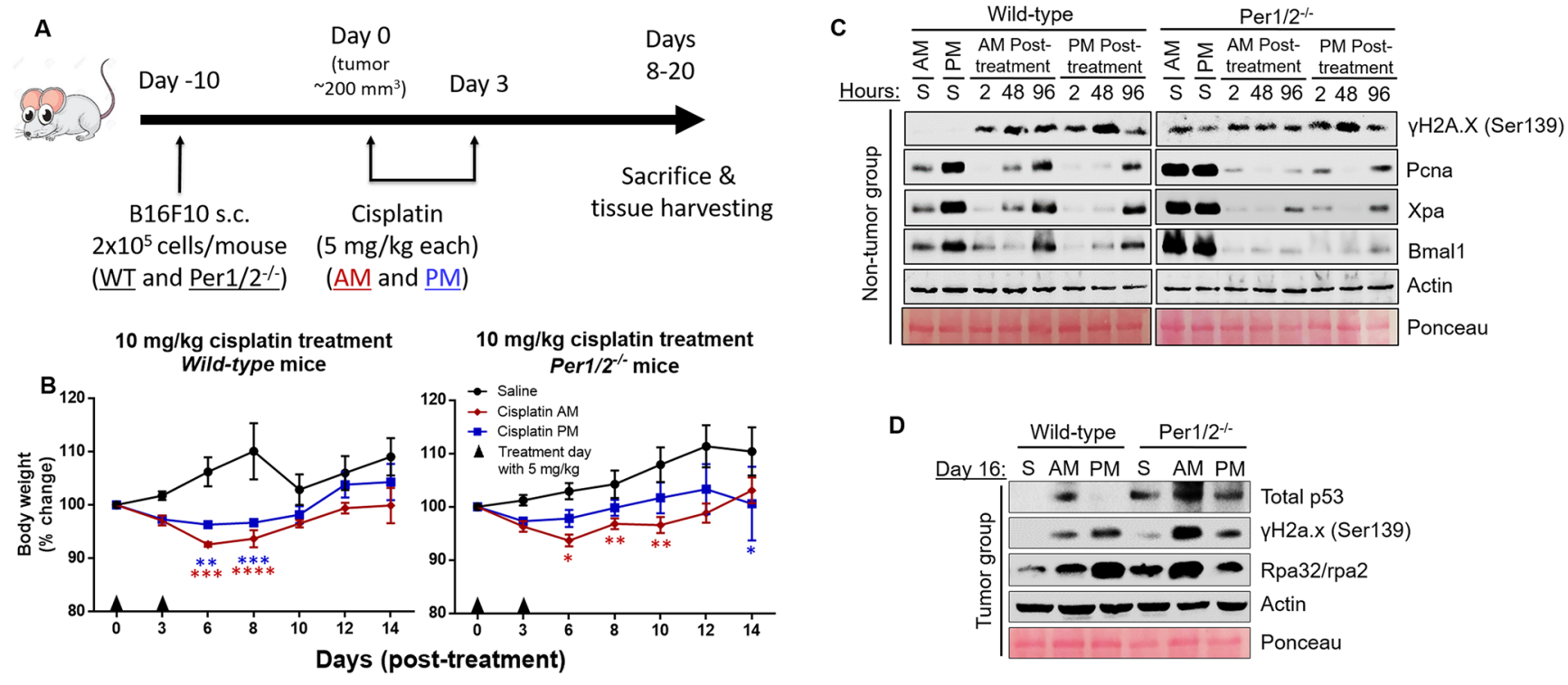

Figure 2: Impact of circadian clock on the molecular dynamics of DNA damage response to cisplatin treatment in the B16F10 melanoma mouse model. (A) Timeline for the study. C57BL/6 wild-type (WT) and Per1/2 ${ }^{-/}$mice were maintained under a LD12:12 cycle and injected (s.c.) with 0.2 million B16F10 melanoma cells. When tumor sizes reached an average of $200 \mathrm{~mm}^{3}$, intraperitoneal cisplatin treatments of $5 \mathrm{mg} / \mathrm{kg}$ (twice) were administered either in the morning (7 AM, ZT0) or evening (7 PM, ZT12). Total body weights were measured every 2 days and reported as percent change $(\mathbf{B})$ in wild-type and Per $1 / 2^{-/}$mice. Mice were sacrificed when tumors crossed 4 times the volume at the start of treatment. Protein levels in response to DNA damage in the kidneys were detected by immunoblotting at selected time points post-cisplatin treatment in non-tumor (C) and tumor-bearing (D) mice. "S" indicates saline treatment, "AM, PM" indicate the times of cisplatin treatment, " 2,48 , and 96 " refer to the hours post-cisplatin treatment of tissue collection, and day 16 tissues in (D) were collected at 7 PM (ZT12). Statistical analysis was done using two-way ANOVA with Tukey's multiple comparison test for post-hoc testing relative to saline. $\mathrm{n}=5-7$ mice per group. ${ }^{*}=\mathrm{p}<0.05,{ }^{* *}=\mathrm{p}<0.01,{ }^{* * *}=\mathrm{p}<0.001,{ }^{* * * *}=\mathrm{p}<0.0001$. Error bars $=$ S.E.M. 
(2.0- and 1.4-fold increases, respectively), whereas the $\mathrm{CD}^{+} \mathrm{T}$ cell population was significantly higher only in the spleen tissues (1.6-fold increase) of Per $1 / 2^{-/}$mice compared to wild-types (Figures 3C-3D). In the tumorbearing mice, tumor-infiltrating lymphocytes were significantly higher in Per $1 / 2^{-/-}$mice than in wild-type mice, with a 6.9-fold and 5.4-fold increase for $\mathrm{CD}^{+}$ and $\mathrm{CD}^{+} \mathrm{T}$ cell populations, respectively (Figure 3E). Collectively, the more robust $\mathrm{CD}^{+}$and $\mathrm{CD}^{+} \mathrm{T}$ cell populations and infiltration to tumor sites of the Per $1 / 2^{-/}$ mice suggests that clock-regulated immune function plays an important role in sensitizing melanoma tumors to cisplatin treatment.

\section{Clock-controlled repair of cisplatin-DNA adducts in human blood cells}

To translate our findings in mouse models to humans and delineate a mechanism underlying the chronotherapeutic outcomes of cisplatin such as leucopenia and neutropenia [25, 30-32], we studied human blood samples and cell lines. Whereas the animal studies demonstrated convincingly that cisplatin treatment effects are driven by the endogenous circadian clock, the possibility remains that some of the observed effects were mediated by behavior that is influenced indirectly by the circadian clock and/or by the light/dark regimen.
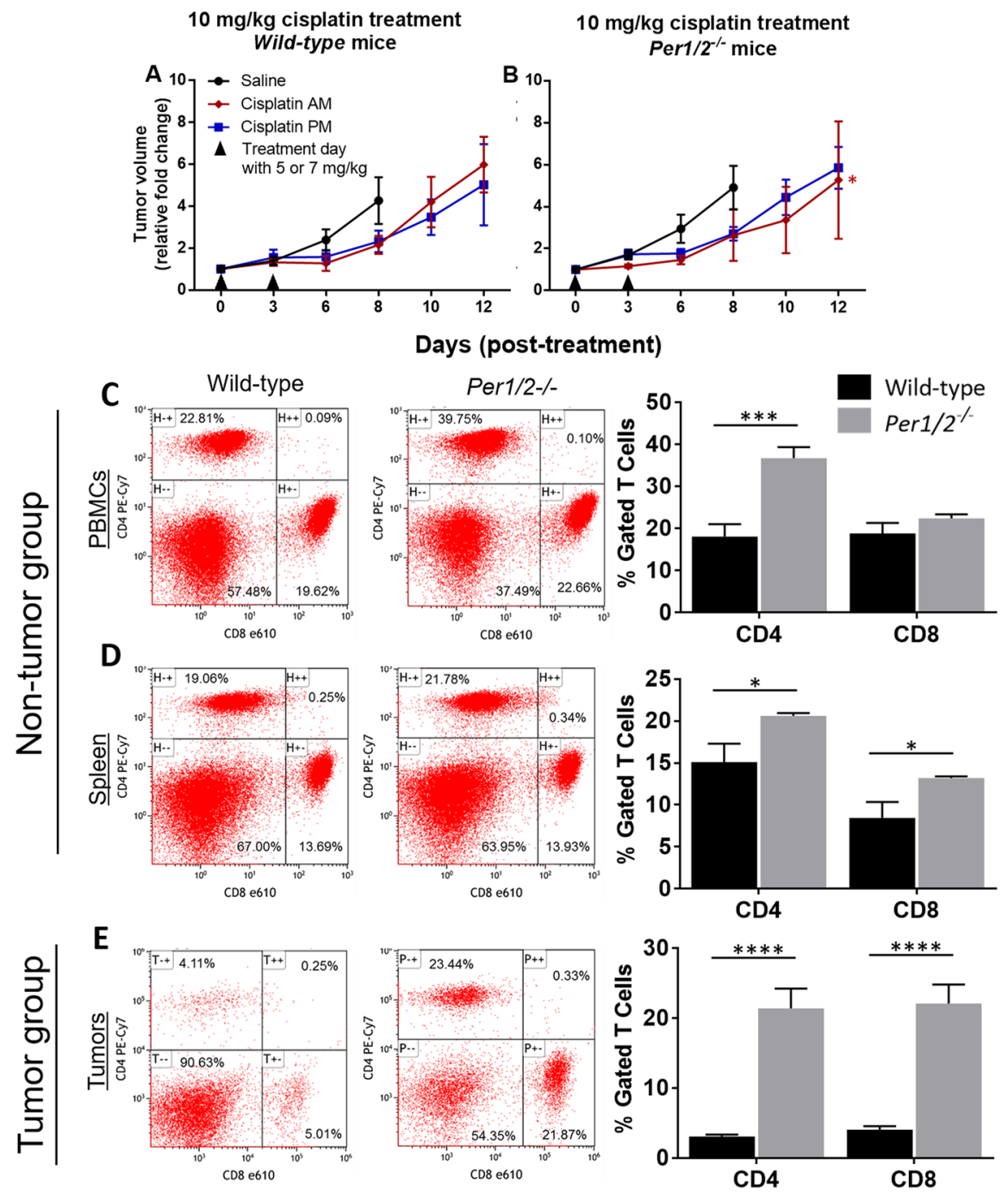

Figure 3: Influence of circadian clock in immune function against melanoma tumors. (A-B) Tumor volume measurements from the experiment described in Figure 2. Wild-type and Per $1 / 2^{-/-}$mice were randomly divided into non-tumor and tumor groups. The mice in the tumor group were injected with 0.2 million B16F10 melanoma tumor cells. When tumors reached an average size of $650 \mathrm{~mm}^{3}$ in the tumor-bearing group, animals in both groups were sacrificed at ZT5 and blood, spleen, and tumors (in the tumor group) were harvested. (CE) $\mathrm{CD}^{+} \mathrm{T}$ cells and $\mathrm{CD} 8^{+} \mathrm{T}$ cells (excluding double-stained populations) were analyzed by flow cytometry. Statistical analysis of the rate of tumor growth was done using linear regression and planned contrasts (for tumor volume, $\mathrm{n}=5-7$ ), and two-way ANOVA with Bonferroni multiple comparison test (for immune function, $\mathrm{n}=3-6$ ). ${ }^{*}=\mathrm{p}<0.05,{ }^{* * *}=\mathrm{p}<0.001,{ }^{* * * *}=\mathrm{p}<0.0001$. Error bars $=$ S.E.M. 
Therefore, this leaves open the possibility that sleep/wake cycles or feeding/fasting cycles also mediated some of the observed effects. To rule out such indirect effects and corroborate that the observed effects are driven directly by the endogenous circadian clock, we conducted a simulated shift work study in a highly controlled laboratory setting. The study included a 24-hour "constant routine," - 24 hours of constant light and temperature, fixed semirecumbent posture, constant wakefulness, and fixed hourly calorie intake - following exposure to simulated shift work. This study design allowed us to control the sleep/ wake and feeding/fasting cycles and dissociate them from the circadian cycle (Figure 4A).

Blood samples were collected from healthy subjects during a 24-hour constant routine after they had been exposed to three days of simulated day shift or night shift conditions. Samples were collected every 3 hours during the constant routine, at ZT2, ZT5, etc., where ZT0 corresponded to lights on at $6 \mathrm{AM}$ in the simulated day shift condition and at 6PM in the simulated night shift condition. Assessment of the dim light melatonin onset (DLMO) in the two conditions during the constant routine demonstrated an approximately 90-minute shift in the onset of melatonin production in the night shift condition as compared to the day shift condition (data not shown), showing that the night shift condition had only a small circadian phase shifting effect and did not induce a complete reversal of the endogenous circadian rhythm. As a consequence, the timing of the sleep/wake cycle was dissociated completely from the endogenous circadian cycle, allowing the effects of the two cycles to be disentangled completely by comparing the two conditions during the constant routine.

Samples taken at ZT2 and ZT14 were treated, ex vivo, with $10 \mu \mathrm{M}$ cisplatin to study the repair of cisplatinDNA adducts by time of day. For the simulated day shift condition, treatment in the evening (ZT14, 8 PM) resulted in less cisplatin-DNA adduct accumulation, possibly indicating better repair, over a 24-hour period (Figure $4 \mathrm{~B})$. For the simulated night shift condition, treatment in the evening (ZT2, 8 PM) also resulted in less cisplatinDNA adduct accumulation over a 24-hour period (Figure 4C) - despite the fact that prior wakefulness was much shorter at that time in the simulated night shift condition. This finding shows that the cisplatin effect on DNA adduct accumulation is tied to the clock time of administration, which in this study design corroborates the animal studies in that the effect is driven by the endogenous circadian clock. At the same time, we ruled out the possibility that prior sleep/wake and feeding/fasting patterns could explain the observations, isolating the effect to a direct circadian clock.

Noteworthy in the human blood cells and divergent from our in vivo mice experiments is the observation that cisplatin-DNA adduct formation increased over the time course from 2 to 24 hours post-treatment. This may reflect slow uptake of cisplatin by blood cells through either the passive diffusion or transporter mechanisms or a slower rate of NER, or simply a lack of circulation in the incubated blood samples. To further investigate the repair activity of cisplatin-DNA adducts in human blood cells, a multiplex assay was performed and subjected to cosinor analysis. This showed significant 24-hour rhythmicity of the XPA gene transcript in the blood samples collected every 3 hours during the constant routine, in both conditions (Figure 4D). The peak time (acrophase) of $X P A$ rhythmicity showed a non-significant phase delay by clock time of 2.6 hours $( \pm 2.5$ hours, $\mathrm{p}=0.32)$ in the simulated night shift condition relative to the day shift condition. Per the design of the study, which induced a similarly small delay in the endogenous circadian clock that was uncoupled from the light/dark and behavioral (sleep/wake, feeding/fasting) schedule, this indicates that the observed XPA rhythmicity was driven specifically by the endogenous circadian clock. Additionally, chromatin-immunoprecipitation (ChIP) showed that the circadian clock protein BMAL1 transcriptionally binds to the promoter region of the human $X P A$ gene in human melanoma cells (Figures 4E-4F), further supporting a direct link with the endogenous circadian clock. Collectively, these results suggest that DNA repair via NER is enhanced in the evening, which would explain the improved outcomes of evening cisplatin treatment in humans [25, 30-32].

\section{DISCUSSION}

The chronotherapeutic application of cisplatin is a balancing act between maximizing the treatment of tumors and minimizing side effects. To find the right balance, it is important to understand the mechanisms that underlie chronotherapeutic outcomes. Proposed mechanisms have been based on speculation and computational modeling based on cell cycle phases and DNA repair pathways [43] lacking corroborating experimental data. Our findings help to fill a critical gap in knowledge. We summarize our results in the model in Figure 5, focusing on both chronotolerance and chronoefficacy.

\section{Chronotolerance}

Toxicities associated with most chemotherapeutic agents, including cisplatin, are a major limitation in the treatment of cancers. Over the past few decades, it has become increasingly evident in rodent and human studies that toxicity of cisplatin can be modulated by time of day of treatment $[11,25,44]$. Our results in body weight loss by time of day (Figure 2B) align with previous findings that demonstrate circadian variation in the tolerance of cisplatin treatment [11]. From a mechanistic perspective, we made the important observations that the modulation 
by time of day in the repair of cisplatin-induced lesions in wild-type mice was tied to the endogenous circadian clock and abolished in the genetically clock-disrupted Per $1 / 2^{-1-}$ mice. Clock control of the NER system has previously been shown in brain and liver tissues $[35,45]$. Our data show that the NER system is functionally similar in kidney tissue. The kidney is the site of the most cisplatin damage and highest toxicity in patients (Supplementary Figure 1), making this finding clinically relevant with regard to understanding nephrotoxicity.

Relevant to melanoma, XPA is rate-limiting in the NER system for the elimination of bulky DNA lesions from ultraviolet radiation as well as platinating agents during therapy $[16,38,45,46]$. NER is the sole repair mechanism for the elimination of bulky DNA base lesions [16], thereby ruling out the possibility of involvement of other DNA repair pathways, such as direct, mismatch, base excision and recombination/crosslink repairs in our experimental models. In addition, NER is the only system repairing these bulky lesions that has been shown to be directly regulated by the circadian clock [35], and the protein expression of XPA in kidney tissue is consistent with circadian control (Figure 2C). In humans, XPA is transcriptionally regulated by the clock through direct binding of the clock protein, Bmal1, to its promoter region (Figures 4E-4F). Furthermore, our laboratory study with human subjects, which controlled for the influence of other behavioral rhythms such as the sleep/ wake cycle, showed significant 24-hour XPA transcript rhythmicity in human blood samples specifically linked to the endogenous circadian clock (Figure 4D). The influence of $X P A$ in cisplatin treatment toxicity shown here ex vivo implicates the endogenous circadian clock in regulating NER through XPA in humans. Further experiments will
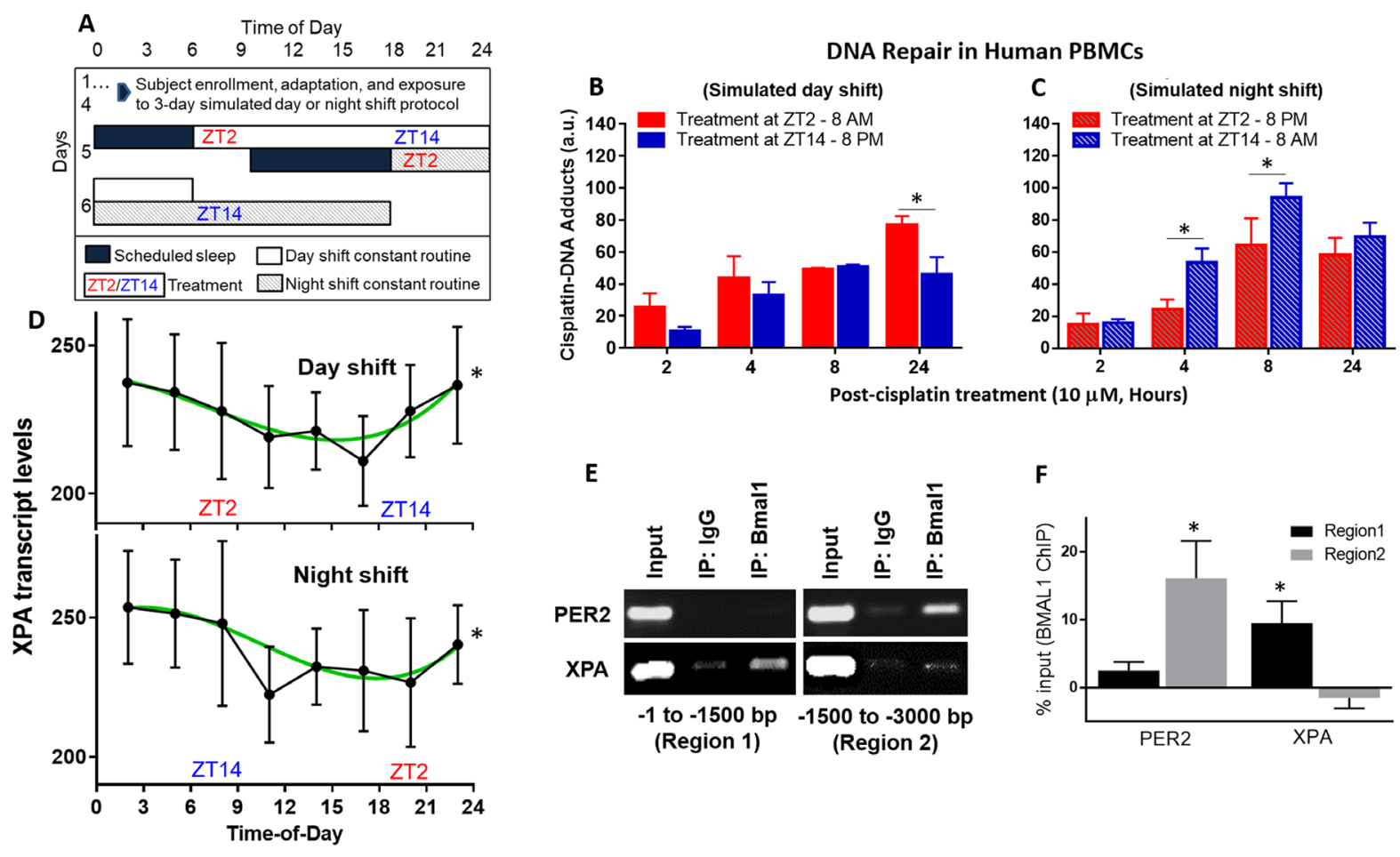

Figure 4: Repair of cisplatin-DNA adducts by time of day in human blood samples. (A) Healthy human subjects were studied in-laboratory and subjected to 3 days of a simulated day shift schedule (B, control condition) or a simulated night shift condition (C, experimental condition). This was followed by a 24-hour constant routine protocol during which blood was drawn at 3-hour intervals (ZT2, ZT5, etc.) Blood samples collected at ZT2 and ZT14 (8 AM and 8 PM, respectively, in the day shift condition, or 8 PM and 8 AM in the night shift condition) were immediately treated with $10 \mu \mathrm{M}$ cisplatin. Blood samples were incubated and fractions were collected between 2 and 24 hours later to isolate PBMCs. Genomic DNA was purified and probed for cisplatin-DNA adduct levels with an $\alpha-\mathrm{Pt}-(\mathrm{GpG})$ antibody using a slot-blot assay. (D) mRNA was isolated from the blood samples and gene expression for XPA, the rate-limiting factor in NER, was analyzed using the NanoString multiplex assay. (E) DNA-protein interaction between the Bmall and XPA is shown in the first 3,000 base pair promoter region of human melanoma SKMEL-27 cells using a ChIP assay. PER2 is a circadian clock positive control. Input and IgG are experimental positive and negative controls, respectively. (F) Quantitation of Bmal1 binding to promoter regions of PER2 and XPA from ChIP assay, indicating regions of significance after IgG binding subtraction. Statistical analysis was done using two-way ANOVA with $n=3$ subjects per group (B-C) and cosinor analysis with $n=7$ subjects per group (D), and $t$ test with $n=3$ replicates for $E-F$. ${ }^{*}=p<0.05$ for circadian rhythmicity or ChIP binding. Error bars = S.E.M. 
need to be conducted to validate this in vivo and confirm that XPA rhythmicity could be a biomarker useful for personalizing chemotherapy in clinical settings [47].

Another factor that determines the effect of cisplatin sensitivity is its cellular uptake. A few studies have reported that organic cation transporter 2 (OCT2), an influx transporter, and multidrug and toxin extrusion 1 (MATE1), an efflux transporter, contribute to nephrotoxicity [48, 49]. ATP7A has also been implicated in the efflux of cisplatin [50]. Interestingly, a recent study in mice found that OCT2 transcript and protein expression levels are upregulated during the light phase and downregulated during the dark phase of the 24-hour day, while MATE1 was relatively stable throughout the day [51]. Taken together with our results, there is converging evidence that nephrotoxicity is more severe with morning treatment of cisplatin in comparison with evening treatment, in rodent- and humanbased studies.

An additional finding from our study is the temporal variation in PCNA levels in kidney, with increased levels in the evening. PCNA is generally considered a readout of proliferating cells in the S phase [52], and as such should increase in the morning to correspond with increased replication [38, 39]. However, previous studies have also documented the involvement of PCNA protein as a factor in NER and Base Excision Repair (BER) in vitro by enabling the catalytic activity of repair nucleases [53, 54]. The adult mammalian kidney exhibits limited cellular turnover and regenerative capacity compared to other proliferating tissues such as the skin [55]. Our data in kidney tissues suggest that PCNA is more likely involved in DNA repair than in replication. As such, circadian clock involvement in repair processes may provide an explanation for elevated PCNA levels in the evening.

\section{Chronoefficacy}

Tumor resistance is another limitation to the effectiveness of cisplatin chemotherapy, through glutathione-mediated cellular efflux of the drug [3]. Questions have been posed about the circadian rhythms of tumors to target tumor cells at their most sensitive phase to maximize tumor cell death. Thus far, there is insufficient knowledge about the clock and clockregulated machineries within tumors, due to heterogeneity within and between tumors. However, tumors such as osteosarcoma and pancreatic adenocarcinoma in mice and colorectal and breast cancers in humans have shown dysregulated clocks [56-59]. A recent study showed that enhancing circadian clock function in cancer cells can inhibit tumor growth [40].

In our study, we used time-dependent dosing and observed no difference in tumor growth rate in response to cisplatin treatment in wild-type mice (Figures 3A-3B), which may be because the tumors did not have a robust clock to allow targeting of cells in their most sensitive phase. However, we observed that Per $1 / 2^{-/-}$mice generally responded better to cisplatin treatment than wild-type mice especially with morning treatment and with high dose. Immunological data showed a significantly higher presence of $\mathrm{CD}^{+}$and $\mathrm{CD}^{+} \mathrm{T}$ cells in circulation and infiltration to tumor sites in the Per $1 / 2^{-/-}$mice (Figures $3 \mathrm{C}-3 \mathrm{E}$ ). $\mathrm{CD}^{+} \mathrm{T}$ cells in tumors alter glutathione and cysteine metabolism, and abolish cisplatin resistance [60], thus reducing tumor growth rate. Our results did not reveal why the Per $1 / 2^{-/-}$ mice exhibited more robust immune function, but it might be part of a compensatory mechanism due to the loss of a functional clock, which is worth exploring further. Given that the immune system itself is regulated by the circadian
A

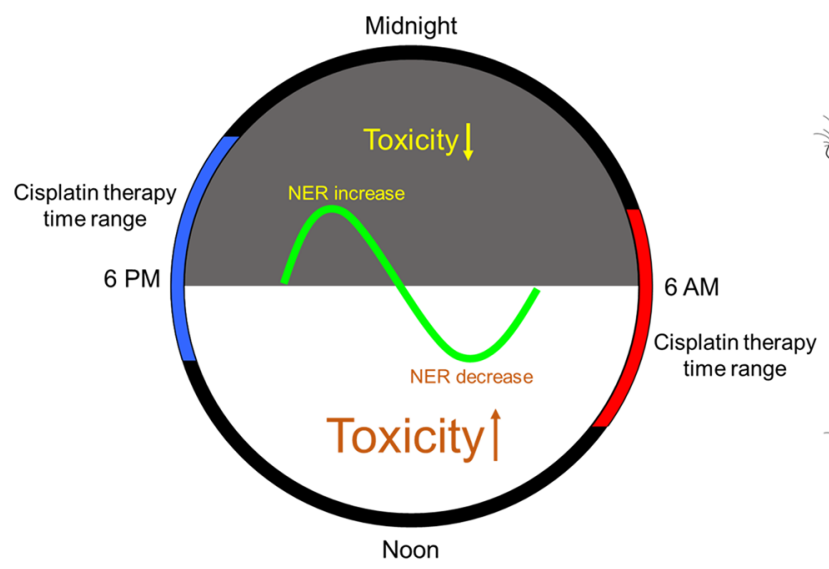

B

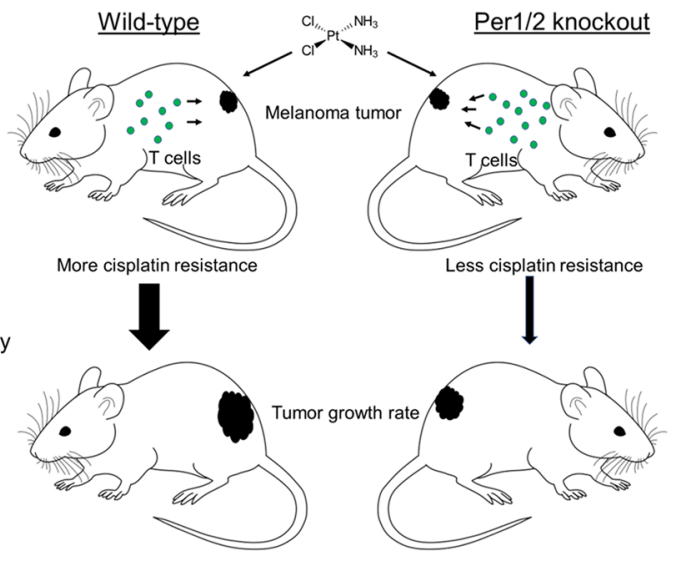

Figure 5: Models showing the impact of the circadian clock on cisplatin toxicity and tumor shrinkage efficacy for melanoma tumors. (A) The rhythmical activity of NER in different tissues is an underlying mechanism responsible for chronotherapeutic outcomes in mouse models and human subjects. (B) There is improved efficacy of cisplatin therapy with a more robust immune system as found in Per $1 / 2^{-/}$mice, probably due to less cisplatin resistance within tumors. 
Table 2: Primer sets for ChIP-PCR

\begin{tabular}{llll}
\hline Name & Direction & Sequence $\mathbf{( - 1}$ to $\mathbf{- 1 5 0 0}$ bp) & Sequence (-1501 to -3000 bp) \\
\hline hPER2 & Forward & CCTAGAGCCCAAAGCACTTG & CTTGACAGTGTCCCCTCCAT \\
hPER2 & Reverse & TTGTTTCTTCCCTCCCATTG & GTACCAGGCAACTGTGCTGA \\
hXPA & Forward & CCTGGCAGTAGCTCATCCTC & AGTCATCAGCAGCAAGACCA \\
hXPA & Reverse & ACACGGCCTAGAGACACAGC & CCAAGAACTGGAAGCTGGAG \\
\hline
\end{tabular}

clock [61, 62], future studies focusing on optimizing chronoimmunotherapy may lead to improved cisplatin treatment efficacy.

\section{CONCLUSIONS}

Using a melanoma mouse model and human blood cells, we mechanistically demonstrated the chronopharmacological effects of cisplatin in attenuating toxicity and improving anti-tumor efficacy. In addition, our results suggest that clock-regulated DNA repair via the NER is a mechanism underlying toxicity outcomes in mice and humans. Genetic disruption of the clock through per $1 / 2^{-/}$loss in mice enhances immune response to melanoma tumors, which further contributes to tumor treatment efficacy. Our human study dissociated endogenous circadian rhythmicity from behavioral (sleep/wake, feeding/fasting) rhythms and linked the chronopharmacological effects of cisplatin specifically to the circadian clock. These findings present exciting prospects for chemotherapy and immunotherapy, as well as other therapies that target DNA damage such as radiotherapy, for cancer patients. This has promising implications for circadian clock manipulation as a novel mechanistic approach to enhancing cancer therapy.

\section{MATERIALS AND METHODS}

\section{Animal experiments}

All animal procedures were in accordance with the National Institutes of Health guidelines and approved by the Institutional Animal Care and Use Committee of Washington State University. 8- to 12-week old male wildtype and Per1/2/- mice on C57BL/6 background [36] were obtained from the Jackson Laboratories. The mice were maintained under a $12 \mathrm{~h} / 12 \mathrm{~h}$ light/dark cycle (light on at 7 AM, ZT0, and off at 7 PM, ZT12) at least 4 weeks before and through the duration of the study.

For tumor studies, B16F10 melanoma cells were purchased from ATCC and cultured in RPMI-1640+10\% FBS. $2 \times 10^{5}$ cells in 50\% matrigel (Corning) were injected into the lower right flank region of each mouse. Body weights were measured using an analytical balance, and tumor volumes were measured using a digital caliper and calculated using the formula: $\mathrm{V}=\left(\mathrm{W}^{2} \mathrm{x} \mathrm{L}\right) / 2$ [63]. Tumor- bearing mice were sacrificed as tumor volumes crossed $4 \mathrm{X}$ the volume at the start of cisplatin treatment (for toxicity and tumor study) or reached an average of $650 \mathrm{~mm}^{3}$ on day 15 (for immunophenotyping). Upon sacrifice, blood, kidney, spleen, lymph nodes, testis, brain, and tumor tissues were harvested for further analysis.

\section{Cisplatin preparation and administration}

Cisplatin was purchased from Sigma-Aldrich (cat. \# PHR-1624). Cisplatin solution was prepared freshly, protected from light, before each treatment by dissolution in sterile $0.9 \%$ saline. The treatment was administered to mice intraperitoneally (in vivo) or spiked into human blood samples (ex vivo).

\section{Immuno-slot blot}

In vivo repair of cisplatin-DNA adducts was measured using the method previously reported by us [46]. Frozen cells and tissue samples were homogenized in liquid nitrogen using a mortar and pestle; genomic DNA was isolated using the QIAamp DNA Mini Kit. The quality and quantity of genomic DNA samples was assessed by using a Nano Drop 2000 spectrophotometer (Thermo Fisher Scientific). Briefly, $300 \mathrm{ng}$ of genomic DNA was used per slot for cisplatin-DNA adduct detection. Genomic DNA was denatured by heating for 10 minutes at $100^{\circ} \mathrm{C}$ using a heat block, and neutralized immediately by placing on ice and adding cold ammonium acetate to a final $1 \mathrm{M}$ concentration. The prepared samples were loaded and bound onto a nitrocellulose membrane, prewet with $6 \mathrm{X}$ saline-sodium citrate (SSC) buffer, by gentle suction filtration using a Bio-Dot SF slot-blot apparatus (Bio-Rad Laboratories). The membrane was baked for 2 hours at $80^{\circ} \mathrm{C}$ in a vacuum oven (Shel Lab) to crosslink the genomic DNA, and subsequently blocked in $1 \mathrm{X}$ PBS with $0.1 \%$ Tween $20(\mathrm{PBS} / \mathrm{T})$ containing 5\% nonfat dry milk (blocking buffer) for 1 hour at room temperature. The membrane was incubated with a 1:3000 dilution of $\alpha$ Pt-(GpG) antibody (Oncolyze, cat. \# R-C18) in icecold $\mathrm{PBS} / \mathrm{T}$ for $12-16$ hours at $4{ }^{\circ} \mathrm{C}$ with gentle shaking. Following three 5-minute PBS/T washes, the membrane was incubated with blocking buffer containing HRPconjugated Rat IgG secondary antibody (Cell Signaling, cat. \# 7077S) and the cisplatin-DNA adduct signal was 
determined using Clarity Western ECL chemiluminescent (Bio-Rad Laboratories) and/or SuperSignal West Femto (Thermo Fisher Scientific) reagent methods and a Bio-Rad ChemiDoc XRS+ imager. Afterwards, the membrane was stained with SYBR gold (Invitrogen) as an internal control by incubating for 1 hour at room temperature, protected from light.

\section{Immunoblotting}

Frozen kidney tissue samples were homogenized in liquid nitrogen using a mortar and pestle, protein lysate was extracted using RIPA lysis buffer $(20 \mathrm{mM}$ Tris- $\mathrm{HCl}$ pH 7.5, 150 mM NaCl, 1 mM Na2EDTA, 1 mM EGTA, $1 \%$ Nonidet P-40, and 1\% sodium deoxycholate), and conventional immunoblotting procedures were used to determine the levels of selected proteins involved in DNA repair, proliferation, and the circadian clock. The following antibodies were used: Actin and XPA (Santa Cruz Biotechnology, cat. \#s sc-1616 and sc-28353 respectively), BMAL1 (Bethyl Laboratories, cat. \# A302616A), and $\gamma \mathrm{H} 2 \mathrm{AX}$ (Ser139), RPA32/RPA2 and PCNA (Cell Signaling Technology, cat. \#s 9718S, 2208, and $2568 \mathrm{~S}$ respectively). The appropriate anti-mouse, antirabbit, anti-rat, and anti-goat HRP-conjugated secondary antibody was used for detection with Clarity Western ECL chemiluminescent (Bio-Rad Laboratories) and/ or SuperSignal West Femto (Thermo Fisher Scientific) reagent method with Bio-Rad ChemiDoc XRS+ imager.

\section{Splenocyte and lymphocyte isolation}

Splenocytes were isolated from whole spleen tissue, and lymphocytes were isolated from whole lymph nodes and from peripheral blood using Lympholyte-M (Cedarlane Laboratories) as previously described by us [64].

\section{Tumor-infiltrating lymphocyte isolation}

Melanoma tumors were isolated and washed in ice-cold PBS $+0.1 \%$ BSA, pushed through a wire mesh screen, resuspended in ice-cold PBS $+0.1 \%$ BSA, and centrifuged at $4^{\circ} \mathrm{C}$ for 1 minute at $480 \mathrm{rpm}$. The supernatant was collected and centrifuged at $4^{\circ} \mathrm{C}$ for 10 minutes at 1,200 $\mathrm{rpm}$. The pellet was resuspended in $37.5 \%$ Percoll (GE Healthcare), then centrifuged at 2,000 rpm for 30 minutes. The lymphocytes were collected, treated with RBC lysis buffer, counted, and resuspended in appropriate amount of PBS $+0.1 \%$ BSA for flow cytometry.

\section{Flow cytometry analysis}

The general flow cytometry method was used as previously described [64]. Isolated cells were incubated with
anti-CD4 and anti-CD8 conjugated with PE-Cy7 and e610 fluorophores, respectively (eBioscience, clone \#s GK1.5 and 53-6.7 respectively), and analyzed by flow cytometry using the Gallios Flow Cytometry Model A94291. Data was analyzed using the Kaluza Analysis Software v1.5.

\section{Chromatin-immunoprecipitation (ChIP) and polymerase chain reaction (PCR) assays}

The ChIP protocol and composition of buffers were performed as previously described by us [65]. Adherent cells were incubated in $1 \%$ formaldehyde in PBS (v/v) for 10 minutes while shaking at room temperature, followed by addition of glycine to a final $0.1 \mathrm{M}$ concentration. Cells were harvested by scraping and washed twice in ice-cold PBS. The harvested cells were lysed in $2 \mathrm{ml}$ of ice-cold cell lysis buffer containing protease inhibitor cocktail (PIC) (Roche) for 10 minutes followed by another 10 minutes of incubation with the addition of $2 \mathrm{ml}$ of ChIP buffer. Lysates were sonicated using a microtip sonicator (Qsonica) at 10\% amplitude and delivering a total energy between 1,200 and 1,500 Joules. The mixture was centrifuged at $4^{\circ} \mathrm{C}$ for 10 minutes at $14,000 \mathrm{rpm}$, then the chromatin supernatant was collected, precleared for 30 minutes at $4{ }^{\circ} \mathrm{C}$ using Protein A/G PLUS-agarose beads (Santa Cruz Biotechnology), and incubated with BMAL1 (Bethyl Laboratories) and IgG (Santa Cruz Biotechnology) antibodies overnight at $4^{\circ} \mathrm{C}$. The next day, immune complexes were recovered for 2 hours at $4^{\circ} \mathrm{C}$ using $40 \mu \mathrm{l}$ of Protein A/G PLUS-agarose beads/ssDNA (Santa Cruz Biotechnology/Sigma-Aldrich), and then washed 4 times with $\mathrm{LiCl}$ wash buffer and twice with TE buffer. The input and immunoprecipitation reactions were eluted with elution buffer and digested with proteinase $\mathrm{K}$ (Qiagen). Thereafter, $\mathrm{NaCl}(\mathrm{BDH})$ was added to a final $200 \mathrm{mM}$ concentration and cross-links were reversed by incubation at $65^{\circ} \mathrm{C}$ for 4-6 hours. DNA was purified using the Qiagen PCR purification kit. ChIP DNA was amplified using the Bio-Rad iCycler Thermal Cycler with 35 cycles of denaturation at $95^{\circ} \mathrm{C}$, annealing at $55^{\circ} \mathrm{C}$, and extension at $72^{\circ} \mathrm{C}$ for 30 seconds each (see Table 2 for primer sets). IgG was used as a negative control and PER2 as a positive control. Afterward, equal volumes of PCR-DNA products were run on a $2 \%$ agarose gel, and imaged with a Bio-Rad ChemiDoc XRS+ imager.

\section{Human studies}

The human study was approved by the Institutional Review Board of Washington State University, and all subjects gave written, informed consent. Healthy human subjects with normal sleep were recruited to the Sleep and Performance Research Center at Washington State University Spokane. Subjects met inclusion criteria described by us previously [66]. They had no current cancer or history of cancer, chemotherapy treatment, or 
radiation treatment. Subjects (ages 25.8 $\pm 3.2,10$ males, 4 females) were randomized to three days of a simulated night shift schedule (LD16:8, sleep opportunity from 10 AM until 6 PM n=7) or a simulated day shift (i.e., control) schedule (LD16:8, sleep opportunity from 10 PM until $6 \mathrm{AM}, \mathrm{n}=7$ ) inside the laboratory. This was followed by a 24-hour laboratory-based constant routine protocol with continuous wakefulness under dim light ( $<50$ lux $)$ with feeding restricted to hourly standardized snacks. The constant routine protocol started at ZT0 at $6 \mathrm{PM}$ in the simulated night shift condition and at $6 \mathrm{AM}$ in the simulated day shift condition. Blood was drawn at 3-hour intervals at ZT2, ZT5, etc. $5 \mathrm{ml}$ samples collected at ZT2 and ZT14 were immediately treated ex vivo with cisplatin to a final concentration of $10 \mu \mathrm{M}(3 \mu \mathrm{g} / \mathrm{ml})$ and incubated at $37^{\circ} \mathrm{C}, 5 \% \mathrm{CO}_{2}$ and $1.3 \% \mathrm{O}_{2}$ (Eppendorf International). $1 \mathrm{ml}$ blood fractions were collected at 2, 4, 8, and 24 hours post-cisplatin treatment. As a negative control, fractions without cisplatin treatment were also collected at 0 hours post-cisplatin treatment. Blood samples were centrifuged at $12,000 \mathrm{x} g$ for 1 minute to separate plasma, treated with $1 \mathrm{ml}$ of RBC lysis buffer, and washed twice with PBS to obtain a cell pellet which was stored at $-80^{\circ} \mathrm{C}$ for further processing (see immuno-slot blot procedure above).

\section{Multiplex assay}

XPA transcript levels were measured using the Nanostring nCounter platform multiplexed assay. Total RNA was measured directly with no amplification or other enzymatic processing. $100 \mathrm{ng}$ of total RNA was used for the assay and data was analyzed using nSolver 3.0 software from Nanostring. First, background values were subtracted and data were normalized with the overall geometric mean of internal control genes. Genes with an expectancy of less than 10 counts with $90 \%$ occurrence were excluded.

\section{Quantitation and statistical analysis}

Signals from imaged blots were quantified using Adobe Photoshop CS6. T test, linear regression, oneway and two-way analysis of variance (ANOVA) was performed using Prism version 6.01 (GraphPad software). Bonferroni and Tukey's multiple comparison tests were used for post-hoc comparisons where appropriate. Oscillations of genes were analyzed using mixed-effects cosinor analysis (SAS software) [67]. The type I error threshold was set to 0.05 .

\section{Author contributions}

Concept and supervision by SG. Animal studies, assays, and analysis performed by PD, KP, RG, AL, and $\mathrm{SG}$. Immunology expertise, training, and antibodies from AL and HZ. Human study and circadian rhythm analyses conducted in collaboration with ES and HVD. Writing of the manuscript by PD, HVD, and SG. Reviews and editing of manuscript by all authors.

\section{ACKNOWLEDGMENTS AND FUNDING}

This work was supported by a grant from the National Institutes of Health (R00ES022640) and WSU College of Pharmacy start-up funds (SG), and in part by the human sleep and cognition laboratory of the Sleep and Performance Research Center at Washington State University (HVD).

\section{CONFLICTS OF INTEREST}

The authors declare that they have no conflicts of interest.

\section{REFERENCES}

1. American Cancer Society (2017). Cancer facts \& figures. (Atlanta, GA: The Society). Available at https://www. cancer.org/research/cancer-facts-statistics/all-cancer-factsfigures/cancer-facts-figures-2017.html. Accessed November 12017.

2. Wu YM, Zhang KJ, Yue XT, Wang YQ, Yang Y, Li GC, Li N, Wang YG. Enhancement of tumor cell death by combining cisplatin with an oncolytic adenovirus carrying MDA-7/IL-24. Acta Pharmacol Sin. 2009; 30: 467-77. https://doi.org/10.1038/aps.2009.16.

3. Kelland L. The resurgence of platinum-based cancer chemotherapy. Nat Rev Cancer. 2007; 7: 573-84. https:// doi.org/10.1038/nrc2167.

4. National Library of Medicine (U.S.). ClinicalTrials.gov linking patients to medical research. Bethesda (MD): U.S. National Library of Medicine, National Institutes of Health, Dept. of Health \& Human Services; 2000.

5. Jamieson ER, Lippard SJ. Structure, Recognition, and Processing of Cisplatin-DNA Adducts. Chem Rev. 1999; 99: 2467-98.

6. Soengas MS, Lowe SW. Apoptosis and melanoma chemoresistance. Oncogene. 2003; 22: 3138-51. https://doi. org/10.1038/sj.onc.1206454.

7. Miller AJ, Mihm MC Jr. Melanoma. N Engl J Med. 2006; 355: 51-65. https://doi.org/10.1056/NEJMra052166.

8. Dakup P, Gaddameedhi S. Impact of the Circadian Clock on UV-Induced DNA Damage Response and Photocarcinogenesis. Photochem Photobiol. 2017; 93: 296303. https://doi.org/10.1111/php.12662.

9. Ramirez-Montagut T, Turk MJ, Wolchok JD, GuevaraPatino JA, Houghton AN. Immunity to melanoma: unraveling the relation of tumor immunity and autoimmunity. Oncogene. 2003; 22: 3180-7. https://doi. org/10.1038/sj.onc.1206462. 
10. Gajewski TF, Schreiber H, Fu YX. Innate and adaptive immune cells in the tumor microenvironment. Nat Immunol. 2013; 14: 1014-22. https://doi.org/10.1038/ni.2703.

11. Levi F, Okyar A, Dulong S, Innominato PF, Clairambault J. Circadian timing in cancer treatments. Annu Rev Pharmacol Toxicol. 2010; 50: 377-421. https://doi.org/10.1146/ annurev.pharmtox.48.113006.094626.

12. Van Dongen HP, Kerkhof GA, Dinges DF. Human circadian rhythms. In: Sehgal A, editor. Molecular Biology of Circadian Rhythms. Hoboken (New Jersey): John Wiley \& Sons; 2004. pp. 255-69.

13. Reppert SM, Weaver DR. Coordination of circadian timing in mammals. Nature. 2002; 418: 935-41. https://doi. org/10.1038/nature00965.

14. Sancar A, Lindsey-Boltz LA, Unsal-Kacmaz K, Linn S. Molecular mechanisms of mammalian DNA repair and the DNA damage checkpoints. Annu Rev Biochem. 2004; 73: 39-85. https://doi.org/10.1146/annurev. biochem.73.011303.073723.

15. Belancio VP, Blask DE, Deininger P, Hill SM, Jazwinski $\mathrm{SM}$. The aging clock and circadian control of metabolism and genome stability. Front Genet. 2014; 5: 455. https://doi. org/10.3389/fgene.2014.00455.

16. Sancar A, Lindsey-Boltz LA, Gaddameedhi S, Selby CP, Ye R, Chiou YY, Kemp MG, Hu J, Lee JH, Ozturk N. Circadian clock, cancer, and chemotherapy. Biochemistry. 2015; 54: 110-23. https://doi.org/10.1021/bi5007354.

17. Lin KK, Kumar V, Geyfman M, Chudova D, Ihler AT, Smyth P, Paus R, Takahashi JS, Andersen B. Circadian clock genes contribute to the regulation of hair follicle cycling. PLoS Genet. 2009; 5: e1000573. https://doi. org/10.1371/journal.pgen.1000573.

18. Bass J, Lazar MA. Circadian time signatures of fitness and disease. Science. 2016; 354: 994-9. https://doi.org/10.1126/ science.aah4965.

19. Shearman LP, Sriram S, Weaver DR, Maywood ES, Chaves I, Zheng B, Kume K, Lee CC, van der Horst GT, Hastings $\mathrm{MH}$, Reppert SM. Interacting molecular loops in the mammalian circadian clock. Science. 2000; 288: 1013-9.

20. Partch CL, Green CB, Takahashi JS. Molecular architecture of the mammalian circadian clock. Trends Cell Biol. 2014; 24: 90-9. https://doi.org/10.1016/j.tcb.2013.07.002.

21. Hughes ME, DiTacchio L, Hayes KR, Vollmers C, Pulivarthy S, Baggs JE, Panda S, Hogenesch JB. Harmonics of circadian gene transcription in mammals. PLoS Genet. 2009; 5: e1000442. https://doi.org/10.1371/journal. pgen.1000442.

22. Cho H, Zhao X, Hatori M, Yu RT, Barish GD, Lam MT, Chong LW, DiTacchio L, Atkins AR, Glass CK, Liddle C, Auwerx J, Downes M, et al. Regulation of circadian behaviour and metabolism by REV-ERB-alpha and REV-ERB-beta. Nature. 2012; 485: 123-7. https://doi. org/10.1038/nature11048.
23. Zhang R, Lahens NF, Ballance HI, Hughes ME, Hogenesch JB. A circadian gene expression atlas in mammals: implications for biology and medicine. Proc Natl Acad Sci U S A. 2014; 111: 16219-24. https://doi.org/10.1073/ pnas. 1408886111.

24. Levi FA, Hrushesky WJ, Blomquist CH, Lakatua DJ, Haus E, Halberg F, Kennedy BJ. Reduction of cisdiamminedichloroplatinum nephrotoxicity in rats by optimal circadian drug timing. Cancer Res. 1982; 42: 950-5.

25. Hrushesky WJ. Circadian timing of cancer chemotherapy. Science. 1985; 228: 73-5.

26. Lévi F. Circadian chronotherapy for human cancers. Lancet Oncol. 2001; 2:307-15. https://doi.org/10.1016/ S1470-2045(00)00326-0.

27. Boughattas NA, Levi F, Fournier C, Hecquet B, Lemaigre G, Roulon A, Mathe G, Reinberg A. Stable circadian mechanisms of toxicity of two platinum analogs (cisplatin and carboplatin) despite repeated dosages in mice. J Pharmacol Exp Ther. 1990; 255: 672-9.

28. Hrushesky WJ, Levi FA, Halberg F, Kennedy BJ. Circadian stage dependence of cis-diamminedichloroplatinum lethal toxicity in rats. Cancer Res. 1982; 42: 945-9.

29. Lévi FA, Zidani R, Vannetzel JM, Perpoint B, Focan C, Faggiuolo R, Chollet P, Garufi C, Itzhaki M, Dogliotti L, lacobelli S, Adam R, Kunstlinger F, et al. Chronomodulated versus fixed-infusion-rate delivery of ambulatory chemotherapy with oxaliplatin, fluorouracil, and folinic acid (leucovorin) in patients with colorectal cancer metastases: a randomized multi-institutional trial. J Natl Cancer Inst. 1994; 86:1608-17. https://doi.org/10.1093/jnci/86.21.1608.

30. Li J, Chen R, Ji M, Zou SL, Zhu LN. Cisplatinbased chronotherapy for advanced non-small cell lung cancer patients: a randomized controlled study and its pharmacokinetics analysis. Cancer Chemother Pharmacol. 2015; 76: 651-5. https://doi.org/10.1007/ s00280-015-2804-X.

31. Lin HX, Hua YJ, Chen QY, Luo DH, Sun R, Qiu F, Mo HY, Mai HQ, Guo X, Xian LJ, Hong MH, Guo L. Randomized study of sinusoidal chronomodulated versus flat intermittent induction chemotherapy with cisplatin and 5-fluorouracil followed by traditional radiotherapy for locoregionally advanced nasopharyngeal carcinoma. Chin J Cancer. 2013; 32: 502-11. https://doi.org/10.5732/cjc.013.10004.

32. Ve rma Y, Chauhan A, Singh H, Sabharwal R, Bharti M, Kaur P. Chronomodulated chemotherapy and concomitant radiotherapy for the management of locally advanced head and neck squamous cell carcinoma. Int J Pharm Sci Res. 2014; 5:1015-22.

33. Liedert B, Pluim D, Schellens J, Thomale J. Adduct-specific monoclonal antibodies for the measurement of cisplatininduced DNA lesions in individual cell nuclei. Nucleic Acids Res. 2006; 34: e47. https://doi.org/10.1093/nar/ gk1051. 
34. Kang TH, Leem SH. Modulation of ATR-mediated DNA damage checkpoint response by cryptochrome 1 . Nucleic Acids Res. 2014; 42: 4427-34. https://doi.org/10.1093/nar/ gku094.

35. Kang TH, Lindsey-Boltz LA, Reardon JT, Sancar A. Circadian control of XPA and excision repair of cisplatinDNA damage by cryptochrome and HERC2 ubiquitin ligase. Proc Natl Acad Sci U S A. 2010; 107: 4890-5. https://doi.org/10.1073/pnas.0915085107.

36. Bae K, Jin X, Maywood ES, Hastings MH, Reppert SM, Weaver DR. Differential functions of mPer1, mPer2, and mPer3 in the SCN circadian clock. Neuron. 2001; 30: 525-36.

37. U.S. Department of Health and Human Services, Food and Drug Administration, Center for Drug Evaluation and Research. Guidance for Industry: Estimating the Maximum Safe Starting Dose in Initial Clinical Trials for Therapeutics in Adult Healthy Volunteers. 2005.

38. Gaddameedhi S, Selby CP, Kaufmann WK, Smart RC, Sancar A. Control of skin cancer by the circadian rhythm. Proc Natl Acad Sci U S A. 2011; 108: 18790-5. https://doi. org/10.1073/pnas.1115249108.

39. Geyfman M, Kumar V, Liu Q, Ruiz R, Gordon W, Espitia F, Cam E, Millar SE, Smyth P, Ihler A, Takahashi JS, Andersen B. Brain and muscle Arnt-like protein-1 (BMAL1) controls circadian cell proliferation and susceptibility to UVBinduced DNA damage in the epidermis. Proc Natl Acad Sci U S A. 2012; 109: 11758-63. https://doi.org/10.1073/ pnas. 1209592109.

40. Kiessling S, Beaulieu-Laroche L, Blum ID, Landgraf D, Welsh DK, Storch KF, Labrecque N, Cermakian N. Enhancing circadian clock function in cancer cells inhibits tumor growth. BMC Biol. 2017; 15: 13. https://doi. org/10.1186/s12915-017-0349-7.

41. Bennett SR, Carbone FR, Karamalis F, Flavell RA, Miller JF, Heath WR. Help for cytotoxic-T-cell responses is mediated by CD40 signalling. Nature. 1998; 393: 478-80. https://doi.org/10.1038/30996.

42. Ridge JP, Di Rosa F, Matzinger P. A conditioned dendritic cell can be a temporal bridge between a CD4+ T-helper and a T-killer cell. Nature. 1998; 393: 474-8. https://doi. org/10.1038/30989.

43. Altinok A, Levi F, Goldbeter A. Identifying mechanisms of chronotolerance and chronoefficacy for the anticancer drugs 5-fluorouracil and oxaliplatin by computational modeling. Eur J Pharm Sci. 2009; 36: 20-38. https://doi.org/10.1016/j. ejps.2008.10.024.

44. Dallmann R, Okyar A, Levi F. Dosing-Time Makes the Poison: Circadian Regulation and Pharmacotherapy. Trends Mol Med. 2016; 22: 430-45. https://doi.org/10.1016/j. molmed.2016.03.004.

45. Kang TH, Reardon JT, Sancar A. Regulation of nucleotide excision repair activity by transcriptional and posttranscriptional control of the XPA protein. Nucleic Acids
Res. 2011; 39: 3176-87. https://doi.org/10.1093/nar/ gkq1318.

46. Gaddameedhi S, Kemp MG, Reardon JT, Shields JM, Smith-Roe SL, Kaufmann WK, Sancar A. Similar nucleotide excision repair capacity in melanocytes and melanoma cells. Cancer Res. 2010; 70: 4922-30. https:// doi.org/10.1158/0008-5472.CAN-10-0095.

47. Kang TH, Sancar A. Circadian regulation of DNA excision repair: implications for chrono-chemotherapy. Cell Cycle. 2009; 8: 1665-7. https://doi.org/10.4161/cc.8.11.8707.

48. Filipski KK, Mathijssen RH, Mikkelsen TS, Schinkel AH, Sparreboom A. Contribution of organic cation transporter 2 (OCT2) to cisplatin-induced nephrotoxicity. Clin Pharmacol Ther. 2009; 86: 396-402. https://doi.org/10.1038/ clpt.2009.139.

49. Nakamura T, Yonezawa A, Hashimoto S, Katsura T, Inui $\mathrm{K}$. Disruption of multidrug and toxin extrusion MATE1 potentiates cisplatin-induced nephrotoxicity. Biochem Pharmacol. 2010; 80: 1762-7. https://doi.org/10.1016/j. bcp.2010.08.019.

50. Miyashita H, Nitta Y, Mori S, Kanzaki A, Nakayama K, Terada K, Sugiyama T, Kawamura H, Sato A, Morikawa H, Motegi K, Takebayashi Y. Expression of coppertransporting P-type adenosine triphosphatase (ATP7B) as a chemoresistance marker in human oral squamous cell carcinoma treated with cisplatin. Oral Oncol. 2003; 39: 157-62.

51. Oda M, Koyanagi S, Tsurudome Y, Kanemitsu T, Matsunaga N, Ohdo S. Renal circadian clock regulates the dosing-time dependency of cisplatin-induced nephrotoxicity in mice. Mol Pharmacol. 2014; 85: 715-22. https://doi.org/10.1124/ mol.113.089805.

52. Waga S, Stillman B. The DNA replication fork in eukaryotic cells. Annu Rev Biochem. 1998; 67: 721-51. https://doi. org/10.1146/annurev.biochem.67.1.721.

53. Nichols AF, Sancar A. Purification of PCNA as a nucleotide excision repair protein. Nucleic Acids Res. 1992; 20: 2441-6.

54. Klungland A, Lindahl T. Second pathway for completion of human DNA base excision-repair: reconstitution with purified proteins and requirement for DNase IV (FEN1). EMBO J. 1997; 16: 3341-8. https://doi.org/10.1093/ emboj/16.11.3341.

55. Rinkevich Y, Montoro DT, Contreras-Trujillo H, HarariSteinberg O, Newman AM, Tsai JM, Lim X, VanAmerongen R, Bowman A, Januszyk M, Pleniceanu O, Nusse R, Longaker MT, et al. In vivo clonal analysis reveals lineage-restricted progenitor characteristics in mammalian kidney development, maintenance, and regeneration. Cell Rep. 2014; 7: 1270-83. https://doi.org/10.1016/j. celrep.2014.04.018.

56. Chen ST, Choo KB, Hou MF, Yeh KT, Kuo SJ, Chang JG. Deregulated expression of the PER1, PER2 and PER3 genes 
in breast cancers. Carcinogenesis. 2005; 26: 1241-6. https:// doi.org/10.1093/carcin/bgi075.

57. Oshima T, Takenoshita S, Akaike M, Kunisaki C, Fujii S, Nozaki A, Numata K, Shiozawa M, Rino Y, Tanaka $\mathrm{K}$, Masuda M, Imada T. Expression of circadian genes correlates with liver metastasis and outcomes in colorectal cancer. Oncol Rep. 2011; 25: 1439-46. https://doi. org/10.3892/or.2011.1207.

58. Iurisci I, Filipski E, Reinhardt J, Bach S, Gianella-Borradori A, Iacobelli S, Meijer L, Levi F. Improved tumor control through circadian clock induction by Seliciclib, a cyclindependent kinase inhibitor. Cancer Res. 2006; 66: 10720-8. https://doi.org/10.1158/0008-5472.CAN-06-2086.

59. Zeng ZL, Wu MW, Sun J, Sun YL, Cai YC, Huang YJ, Xian LJ. Effects of the biological clock gene Bmal1 on tumour growth and anti-cancer drug activity. J Biochem. 2010; 148: 319-26. https://doi.org/10.1093/jb/mvq069.

60. Wang W, Kryczek I, Dostal L, Lin H, Tan L, Zhao L, Lu F, Wei S, Maj T, Peng D, He G, Vatan L, Szeliga $\mathrm{W}$, et al. Effector T Cells Abrogate Stroma-Mediated Chemoresistance in Ovarian Cancer. Cell. 2016; 165: 1092105. https://doi.org/10.1016/j.cell.2016.04.009.

61. Druzd D, Matveeva O, Ince L, Harrison U, He W, Schmal C, Herzel H, Tsang AH, Kawakami N, Leliavski A, Uhl O, Yao L, Sander LE, et al. Lymphocyte Circadian Clocks Control Lymph Node Trafficking and Adaptive Immune Responses. Immunity. 2017; 46: 120-32. https://doi. org/10.1016/j.immuni.2016.12.011.

62. Keller M, Mazuch J, Abraham U, Eom GD, Herzog ED, Volk HD, Kramer A, Maier B. A circadian clock in macrophages controls inflammatory immune responses. Proc Natl Acad Sci U S A. 2009; 106: 21407-12. https:// doi.org/10.1073/pnas.0906361106.

63. Jensen MM, Jorgensen JT, Binderup T, Kjaer A. Tumor volume in subcutaneous mouse xenografts measured by microCT is more accurate and reproducible than determined by 18F-FDG-microPET or external caliper. BMC Med Imaging. 2008; 8: 16. https://doi. org/10.1186/1471-2342-8-16.

64. Zhang H, Meadows GG. Chronic alcohol consumption in mice increases the proportion of peripheral memory $\mathrm{T}$ cells by homeostatic proliferation. J Leukoc Biol. 2005; 78: 1070-80. https://doi.org/10.1189/jlb.0605317.

65. Ye R, Selby CP, Chiou YY, Ozkan-Dagliyan I, Gaddameedhi $\mathrm{S}$, Sancar A. Dual modes of CLOCK:BMAL1 inhibition mediated by Cryptochrome and Period proteins in the mammalian circadian clock. Genes Dev. 2014; 28: 198998. https://doi.org/10.1101/gad.249417.114.

66. Whitney P, Hinson JM, Satterfield BC, Grant DA, Honn KA, Van Dongen HP. Sleep Deprivation Diminishes Attentional Control Effectiveness and Impairs Flexible Adaptation to Changing Conditions. Sci Rep. 2017; 7: 16020. https://doi.org/10.1038/s41598-017-16165-z.

67. Mikulich SK, Zerbe GO, Jones RH, Crowley TJ. Comparing linear and nonlinear mixed model approaches to cosinor analysis. Stat Med. 2003; 22: 3195-211. https:// doi.org/10.1002/sim.1560.

68. van Hennik MB, van der Vijgh WJ, Klein I, Elferink F, Vermorken JB, Winograd B, Pinedo HM. Comparative pharmacokinetics of cisplatin and three analogues in mice and humans. Cancer Res. 1987; 47: 6297-301.

69. Reagan-Shaw S, Nihal M, Ahmad N. Dose translation from animal to human studies revisited. FASEB J. 2008; 22: 65961. https://doi.org/10.1096/fj.07-9574LSF.

70. Dhar S, Lippard SJ. Mitaplatin, a potent fusion of cisplatin and the orphan drug dichloroacetate. Proc Natl Acad Sci U S A. 2009; 106: 22199-204. https://doi.org/10.1073/ pnas.0912276106.

71. Scanlon KJ, Newman EM, Lu Y, Priest DG. Biochemical basis for cisplatin and 5-fluorouracil synergism in human ovarian carcinoma cells. Proc Natl Acad Sci U S A. 1986; 83: 8923-5. 